University of Nebraska - Lincoln

DigitalCommons@University of Nebraska - Lincoln

Faculty Papers and Publications in Animal

Science

Animal Science Department

2020

Heat stress and $\boldsymbol{\beta}$-adrenergic agonists alter the adipose transcriptome and fatty acid mobilization in ruminant livestock

Rachel R. Reith

Renae L. Sieck

Pablo C. Grijalva

Erin M. Duffy

Rebecca M. Swanson

See next page for additional authors

Follow this and additional works at: https://digitalcommons.unl.edu/animalscifacpub

Part of the Genetics and Genomics Commons, and the Meat Science Commons

This Article is brought to you for free and open access by the Animal Science Department at DigitalCommons@University of Nebraska - Lincoln. It has been accepted for inclusion in Faculty Papers and Publications in Animal Science by an authorized administrator of DigitalCommons@University of Nebraska Lincoln. 


\section{Authors}

Rachel R. Reith, Renae L. Sieck, Pablo C. Grijalva, Erin M. Duffy, Rebecca M. Swanson, Anna M. Fuller, Kristin A. Beede, Joslyn K. Beard, Duarte E. Diaz, Ty B. Schmidt, Dustin T. Yates, and Jessica L. Petersen 


\title{
Heat stress and $\beta$-adrenergic agonists alter the adipose transcriptome and fatty acid mobilization in ruminant livestock ${ }^{1}$
}

\author{
Rachel R. Reith, ${ }^{\dagger}$ Renae L. Sieck,${ }^{\dagger}$ Pablo C. Grijalva, ${ }^{\dagger}$ Erin M. Duffy, ${ }^{\dagger}$ Rebecca M. Swanson, ${ }^{\dagger}$ \\ Anna M. Fuller, ${ }^{\dagger}$ Kristin A. Beede,${ }^{\dagger}$ Joslyn K. Beard ${ }^{\dagger}$ Duarte E. Diaz, ${ }^{\ddagger}$ Ty B. Schmidt, ${ }^{\dagger}$ \\ Dustin T. Yates, ${ }^{\dagger}$ and Jessica L. Petersen ${ }^{\dagger, 2, \odot}$
}

†Department of Animal Science, University of Nebraska-Lincoln, Lincoln, NE 68583-0908; and ${ }^{\circ}$ Department of Animal \& Comparative Biomedical Sciences, University of Arizona-Tucson, Tucson, AZ 85721

\section{(C) The Author(s) 2020. Published by Oxford University Press on behalf of the American Society} of Animal Science.

This is an Open Access article distributed under the terms of the Creative Commons Attribution Non-Commercial License (http://creativecommons.org/licenses/by-nc/4.0/), which permits non-commercial re-use, distribution, and reproduction in any medium, provided the original work is properly cited. For commercial re-use,please contact journals.permissions@oup.com

Transl. Anim. Sci. 2020.4:S141-S144

doi: $10.1093 /$ tas/txaa122

\section{INTRODUCTION}

Growth and feed efficiency of cattle are improved by supplementation with the beta-adrenergic agonists $(\beta \mathrm{AA})$, ractopamine hydrochloride $\left(\mathrm{RH} ; \beta_{1} \mathrm{AA}\right)$ or zilpaterol hydrochloride $(\mathrm{ZH}$; $\beta_{2}$ AA) (Elam et al., 2009). $\beta$ AA supplementation alters adipose deposition by inhibiting fatty acid biosynthesis and promoting lipolysis of stored triacylglycerols into free fatty acids (FFAs) (Johnson et al., 2014). However, $\beta_{2}$ adrenoceptors ( $\beta A R$ ) desensitize with chronic activation ( $R e$ et al., 1997); supplementation is thus limited to the last 20 to $40 \mathrm{~d}$ of feeding.

The annual economic impact of heat stress (HS) has been estimated to exceed $\$ 2.4$ billion (St-Pierre et al., 2003). Heat-stressed livestock have reduced growth rates, dry matter intake, and average daily gain (Mitlöhner et al., 2001; St-Pierre et al., 2003). In response to acute stress,

${ }^{1}$ This project is based on research that was partially supported by the Nebraska Agricultural Experiment Station with funding from the Hatch Multistate Research capacity funding program (accession number 1011055) from the USDA National Institute of Food and Agriculture. A portion of this work was completed utilizing the Holland Computing Center of the University of Nebraska, which receives support from the Nebraska Research Initiative.

${ }^{2}$ Corresponding author: jessica.petersen@unl.edu

Received April 29, 2020.

Accepted July 8, 2020. signaling pathways for lipolysis of circulating and stored triglycerides are activated, while chronic stress increases lipogenesis and adipogenesis (Campbell et al., 2009; Peckett et al., 2011). In cattle, HS also increases the responsiveness of adipocytes to lipolytic signals, increasing lipolysis (Faylon et al., 2015).

The objective of this study was to understand how HS and $\beta$ AA independently and interactively affect adipose tissue. Prior work identified minimal impact of $\mathrm{RH}$ on metabolic properties (Barnes et al., 2019) and on the transcriptome of skeletal muscle (Kubik et al., 2018). We therefore hypothesized that RH may be primarily affecting adipose; specifically, that lipolytic activity is increased due to heat and $\beta A A$ in an additive fashion. We tested this hypothesis in RH-supplemented lambs and $\mathrm{ZH}$-supplemented cattle exposed to HS for 30 and $21 \mathrm{~d}$, respectively.

\section{MATERIALS AND METHODS}

This study was approved by the Institutional Animal Care and Use Committee at the University of Nebraska-Lincoln, which is accredited by AAALAC International.

For study 1, wether lambs were fed a high-energy feedlot diet for $30 \mathrm{~d}$ under thermal neutral (TN; Temperature Humidity Index $[\mathrm{THI}]=65 ; \mathrm{n}=$ $14)$ or HS (THI $=80 ; n=12)$ conditions and supplemented with ractopamine $\mathrm{HCl}(\mathrm{RH} ; 60 \mathrm{mg} / \mathrm{head} / \mathrm{d})$ 
or none (NS) in a $2 \times 2$ factorial. Thermal neutral lambs were pair-fed to the average intake of $\mathrm{HS}$ lambs. At harvest, subcutaneous fat was flash frozen. Poly- $\mathrm{A}^{+}$selected libraries were sequenced from isolated RNA using $150 \mathrm{bp}$, paired-end reads to a minimum depth of 20 million reads/sample (Michigan State University). After quality control, transcripts as annotated in Oar_rambouillet_v1.0 were quantified (STAR; Dobin et al., 2013). Differential expression (DE) analyses were performed in DESeq2 (Love et al., 2014) with a significance threshold False Discovery Rate (FRD) of 0.05. Exploration of data was performed with DAVID (Huang et al., 2009a, 2009b). To study the main effects of environment and supplement, loci with a significant interaction were removed and the remaining loci reevaluated. Pathway analysis (Qiagen) was conducted on all loci with raw $P<0.05$ for the main effects.

For study 2, Red Angus-based steers were fed a high-energy diet for $21 \mathrm{~d}$ under TN $(n=12$; pair-fed to HS average) or HS (THI $=83 ; n=12)$ conditions and supplemented with zilpaterol hydrochloride $(\mathrm{ZH}$; $8.38 \mathrm{mg} / \mathrm{kg} \mathrm{DM} / \mathrm{d}$ ) or none (NS) in a $2 \times 2$ factorial. At harvest, visceral adipose was flash frozen to determine fatty acid mobilization in a method adapted from Raclot and Groscolas (1993). Briefly, modified Krebs Ringer buffer (MKRB) was made ( $9 \mathrm{~g}$ of KRB [Sigma], $900 \mathrm{~mL}$ dd $\mathrm{H}_{2} \mathrm{O}, 15 \mathrm{mM} \mathrm{NaHCO}_{3}$, $2.5 \mathrm{mM} \mathrm{CaCl}_{2}$ dihydrate, and $4 \%$ fatty acid free $\mathrm{BSA}^{3}$, $\mathrm{pH}$ adjusted to 7.4 and sterilized). Visceral fat was minced, strained $(200 \mu \mathrm{M})$, washed $\left(37^{\circ} \mathrm{C}\right.$ MKRB), and minced again. Adipose $(400 \pm 10 \mathrm{mg})$ was added to $5 \mathrm{~mL}$ MKRB containing 0 or $1 \mu \mathrm{M}$ epinephrine. Samples were incubated in a shaking water bath $(2 \mathrm{~h}$, $\left.37^{\circ} \mathrm{C}\right)$, and the media filtered $(2.4 \mathrm{~cm}$ glass microfiber filter) and stored at $-80{ }^{\circ} \mathrm{C}$. Free fatty acids were quantified by colorimetric detection (Sigma Aldrich Free Fatty Acid Quantification Kit), read at $570 \mathrm{~nm}$ (BioTek EPOCH). Concentrations were determined using a 0 to $4 \mathrm{nmol} / \mu \mathrm{L}$ standard curve for palmitic acid and analyzed using the PROC MIXED procedure (SAS Institute Inc., Cary, NC). $P<0.05$ were considered significant.

\section{RESULTS}

Seventy-one loci were DE $\left(P_{\text {adj }}<0.05\right)$ due to a temperature by supplement interaction. Differential expression loci with the greatest $\operatorname{logFC}$ include G-protein-coupled receptor, GPRC5A, and others involved in G-protein receptor signaling (e.g., $S A A 1$, $N P W$, and $N G E F$; Table 1). When loci DE due to interaction were removed, RBM3 and $A T X N 7 L 1$ were DE $\left(P_{\text {adj }}<0.1\right)$ due to temperature (Table 2$)$.
Table 1. Loci DE due to an interaction of environment and supplement in adipose of wether lambs

\begin{tabular}{lcc}
\hline \hline Gene ID & $P$-value & Adjusted $P$-value \\
\hline GPRC5A & $1.10 \mathrm{E}-07$ & $<0.001$ \\
FOSB & $1.43 \mathrm{E}-04$ & 0.033 \\
FOS & $1.92 \mathrm{E}-06$ & 0.002 \\
SAA2 & $1.09 \mathrm{E}-04$ & 0.023 \\
SERPINF2 & $6.63 \mathrm{E}-08$ & $<0.001$ \\
SAA1 & $3.31 \mathrm{E}-05$ & 0.012 \\
NPW & $2.33 \mathrm{E}-04$ & 0.048 \\
FMOD & $4.08 \mathrm{E}-05$ & 0.014 \\
C1QTNF3 & $2.55 \mathrm{E}-06$ & 0.002 \\
SFRP4 & $8.97 \mathrm{E}-07$ & 0.001 \\
TPSB2 & $2.09 \mathrm{E}-05$ & 0.008 \\
LTC4S & $449 \mathrm{E}-09$ & $<0.001$ \\
NGEF & $9.53 \mathrm{E}-05$ & 0.025 \\
$I L 34$ & $3.23 \mathrm{E}-05$ & 0.012 \\
\hline
\end{tabular}

Table 2. Loci DE in wether lamb adipose due to HS

\begin{tabular}{lccc}
\hline \hline Gene ID & $\log _{2}$ fold change & $P$-value & Adjusted $P$-value \\
\hline$R B M 3$ & -0.888 & $2.53 \mathrm{E}-07$ & 0.006 \\
$A T X N 7 L 1$ & 0.550 & $1.06 \mathrm{E}-05$ & 0.10 \\
\hline
\end{tabular}

No loci were DE due to supplement. Pathway analysis predicted the "Adipogenesis Pathway" to be altered $(P<0.001)$ but without clear directionality of dysregulation. The top regulator effect networks included the biological functions: concentration of fatty acid, molecule transport, and cell migration (Table 3).

There was no interaction between environment and supplement for ex vivo FFA mobilization from steer adipose. Free fatty acid concentration did not differ among groups at $0 \mu \mathrm{M}$ (Fig. 1). At $1 \mu \mathrm{M}$ epinephrine, FFA was greater $(P<0.05)$ in TN than HS. All treatment groups responded to epinephrine, with $\mathrm{TN} / \mathrm{ZH}$ having the highest concentration (Fig. 1).

\section{DISCUSSION}

We identified interacting and independent effects of HS and $\beta \mathrm{AA}$ supplementation on adipogenesis and lipolysis in sheep, as indicated by gene expression. We also found that fatty acid mobilization was impaired by HS but enhanced by $\beta \mathrm{AA}$ supplementation in cattle. Zilpaterol hydrochloride supplementation in heat-stressed cattle increased the FFA-mobilization response to epinephrine even after $21 \mathrm{~d}$, but the response was less due to HS.

Transcriptome analyses in wethers did not clearly predict whole-pathway changes due to the interaction of HS and $\beta$ AA. Several loci implicated 
Table 3. Top regulator effect networks in the adipose transcriptome due to HS

\begin{tabular}{llr}
\hline \hline Regulators & \multicolumn{1}{c}{ Disease and functions } & Consistency score \\
\hline CD28, CD3 group, LCN2, RETN & Concentration of fatty acid, transport of molecule & 7.217 \\
CD3 group & Concentration of fatty acid, migration of cells & 6.425 \\
\hline
\end{tabular}

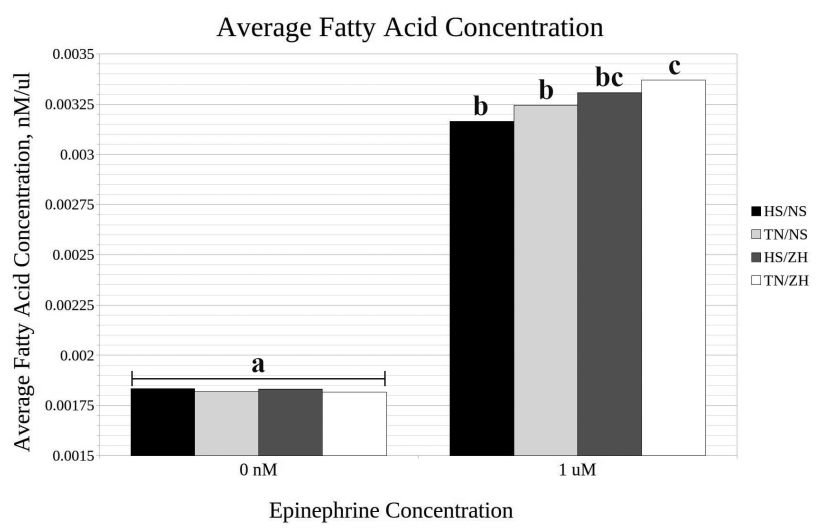

Figure 1. Mean fatty acid concentration for each treatment group. Superscripts denote a significance $(P<0.05)$.

however are components of G-protein receptor pathways, through which $\beta$ AA signal. Others such as FOS and FOSB are associated with inflammation (Wagner and Efrel, 2005). Additional data from this study demonstrated an inflammatory response due to $\mathrm{HS}$ that was moderated by $\mathrm{RH}$ (Swanson et al., 2020). Heat stress alone altered expression of two loci in adipose. RBM3 encodes for a protein induced in response to hypoxia and cold shock (Wellmann et al., 2010); it was downregulated in HS lambs. ATXN7L1 is associated with neurological disorders (Carlson et al., 2009), but Komolka et al. (2016) reported it is downregulated in the longissimus dorsi of cattle with greater intramuscular fat. Increased $A T X N 7 L 1$ expression in HS lambs could therefore contribute to the observed decrease in fat (Swanson et al., 2020). Pathway analyses predicted adipogenesis to be dysregulated due to HS. This was not surprising, considering that there are presumably mechanisms whereby HS affects adipose tissue not apparent from RNA analyses alone. Two regulator effect networks identified affected fatty acid concentrations and movement, supporting our hypothesis that HS impairs fat homeostasis. Conversely, we did not identify transcriptome changes in subcutaneous adipose attributable solely to RH. It is worth noting that samples were collected after $30 \mathrm{~d}$ on $\mathrm{RH}$, and thus it is possible that $\beta$ AR had been desensitized. The chronic effect $\beta A A$ on adipose can also be difficult to observe from a single time-point, as $\beta \mathrm{AA}$ enhance lipid mobilization but increase fatty acid synthesis (Yang and McElligott, 1989).

In cattle, HS and $\mathrm{ZH}$ supplementation each modified fatty acid mobilization of adipose due to epinephrine independently, although the two factors did not have interacting effects. Zilpaterol hydrochloride preferentially binds $\beta_{2} \mathrm{AR}$, and thus the heightened effect could be due to epinephrine acting on $\beta_{1} \mathrm{AR}$ with greater frequency than it would in the absence of $\mathrm{ZH}$. It is more likely, however, that exposure to both epinephrine and $\mathrm{ZH}$ had an additive effect. Decreased FFA mobilization due to HS was possibly an effect of chronic exposure. In study 1 , HS caused increased circulating epinephrine (Swanson et al., 2020). If steers in study 2 responded likewise, it is reasonable to speculate that their $\beta$ AR became desensitized and less responsive to epinephrine. Acute HS increases adipocyte responses to lipolytic signals (Faylon et al., 2015), but we postulate that chronic HS decreased responsiveness due to downregulated $\beta A R$.

\section{IMPLICATIONS}

Loci in adipose have altered expression due to the combined impact of HS and $\beta$ AA supplementation. Specific loci associated with inflammation were observed, warranting additional investigation in order to fully elucidate their role in adipose HS. We also provide evidence that increased lipolysis is a mechanism by which $\mathrm{ZH}$ can reduce carcass fat and promote feed efficiency. Conversely, HS impaired fatty acid mobilization, presumably via $\beta A R$ desensitization resulting from chronic stimulation. Finally, no interacting effects of HS and $\beta$ AA supplementation on mechanisms that would impact animal wellbeing were apparent. Building a better understanding of the mechanisms by which animals respond to HS and $\beta$ AA supplementation will aid in generating improved management practices to improve sustainability of livestock production.

Conflict of interest statement. None declared.

\section{LITERATURE CITED}

Barnes, T. L., C. N. Cadaret, K. A. Beede, T. B. Schmidt, J. L. Petersen, and D. T. Yates. 2019. Hypertrophic muscle growth and metabolic efficiency were impaired by chronic 
heat stress, improved by zilpaterol supplementation, and not affected by ractopamine supplementation in feedlot lambs1. J. Anim. Sci. 97:4101-4113. doi:10.1093/jas/skz271

Campbell, J., T. Hawke, and M. Riddell. 2009. Glucocorticoids are capable of stimulating both lipolysis and adipogenesis in 3T3-L1 adipocytes. Can. J. Diabetes 33:302-303. doi:10.1016/S1499-2671(09)33296-7

Carlson, K. M., J. M. Andresen, and H. T. Orr. 2009. Emerging pathogenic pathways in the spinocerebellar ataxias. Curr. Opin. Genet. Dev. 19:247-253. doi:10.1016/j. gde.2009.02.009

Dobin, A., C. A. Davis, F. Schlesinger, J. Drenkow, C. Zaleski, S. Jha, P. Batut, M. Chaisson, and T. R. Gingeras. 2013. STAR: ultrafast universal RNA-seq aligner. Bioinformatics. 29:15-21. doi:10.1093/bioinformatics/ bts635

Elam, N. A., J. T. Vasconcelos, G. Hilton, D. L. VanOverbeke, T. E. Lawrence, T. H. Montgomery, W. T. Nichols, M. N. Streeter, J. P. Hutcheson, D. A. Yates, et al. 2009. Effect of zilpaterol hydrochloride duration of feeding on performance and carcass characteristics of feedlot cattle. J. Anim. Sci. 87:2133-2141. doi:10.2527/jas.2008-1563

Faylon, M. P., L. H. Baumgard, R. P. Rhoads, and D. M. Spurlock. 2015. Effects of acute heat stress on lipid metabolism of bovine primary adipocytes. J. Dairy Sci. 98:8732-8740. doi:10.3168/jds.2015-9692

Huang, D. W., B. T. Sherman, and R. A. Lempicki. 2009a. Systematic and integrative analysis of large gene lists using DAVID Bioinformatics Resources. Nat. Protoc. 4:44-57. doi:10.1038/nprot.2008.211

Huang, D. A. W., B. T. Sherman, and R. A. Lempicki. 2009 b. Bioinformatics enrichment tools: paths toward the comprehensive functional analysis of large gene lists. Nucleic Acids Res. 37:1-13. doi:10.1093/nar/gkn923

Johnson, B. J., S. B. Smith, and K. Y. Chung. 2014. Historical overview of the effect of $\beta$-adrenergic agonists on beef cattle production. Asian-Australas. J. Anim. Sci. 27:757766. doi:10.5713/ajas.2012.12524

Komolka, K., S. Ponsuksili, E. Albrecht, C. Kühn, K. Wimmers, and S. Maak. 2016. Gene expression profile of Musculus longissimus dorsi in bulls of a Charolais $\times$ Holstein F2-cross with divergent intramuscular fat content. Genom. Data 7:131-133. doi:10.1016/j.gdata.2015.12.023

Love, M. I., W. Huber, and S. Anders. 2014. Moderated estimation of fold change and dispersion for RNA-seq data with DESeq2. Genome Biol. 15:550. doi:10.1186/ s13059-014-0550-8

Kubik, R. M., S. M. Tietze, T. B. Schmidt, D. T. Yates, and J. L. Petersen. 2018. Investigation of the skeletal muscle transcriptome in lambs fed $\beta$ adrenergic agonists and subjected to heat stress for $21 \mathrm{~d} 1$. Transl. Anim. Sci. 2(Issue Suppl. 1):S53-S56. doi:10.1093/tas/txy053

Mitlöhner, F. M., J. L. Morrow, J. W. Dailey, S. C. Wilson, M. L. Galyean, M. F. Miller, and J. J. McGlone. 2001. Shade and water misting effects on behavior, physiology, performance, and carcass traits of heat-stressed feedlot cattle. J. Anim. Sci. 79:2327-2335. doi:10.2527/2001.7992327x

Peckett, A. J., D. C. Wright, and M. C. Riddell. 2011. The effects of glucocorticoids on adipose tissue lipid metabolism. Metabolism 60:1500-1510. doi:10.1016/j. metabol.2011.06.012

Raclot, T., and R. Groscolas. 1993. Differential mobilization of white adipose tissue fatty acids according to chain length, unsaturation, and positional isomerism. J. Lipid Res. 34:1515-1526.

Re, G., P. Badino, A. Novelli, and G. Girardi. 1997. Effects of clenbuterol as a repartitioning agent on beta-adrenoceptor concentrations in heart, bronchi and brain of veal calves. Vet. J. 153:63-70. doi:10.1016/s1090-0233(97)80009-3

St-Pierre, N., B. Cobanov, and G. Schnitkey. 2003. Economic losses from heat stress by US livestock industries. J. Dairy Sci. 86:E52-E77. doi:10.3168/jds.S0022-0302(03)74040-5

Swanson, R. M., R. G. Tait, B. M. Galles, E. M. Duffy, T. B. Schmidt, J. L. Petersen, and D. T. Yates. 2020. Heat stress-induced deficits in growth, metabolic efficiency, and cardiovascular function coincided with chronic systemic inflammation and hypercatecholaminemia in ractopamine-supplemented feedlot lambs. J. Anim. Sci. 98. doi:10.1093/jas/skaa168

Wagner, E. F., and R. Eferl. 2005. Fos/AP-1 proteins in bone and the immune system. Immunol. Rev. 208:126-140. doi:10.1111/j.0105-2896.2005.00332.x

Wellmann, S., M. Truss, E. Bruder, L. Tornillo, A. Zelmer, K. Seeger, and C. Bührer. 2010. The RNA-binding protein RBM3 is required for cell proliferation and protects against serum deprivation-induced cell death. Pediatr. Res. 67:35-41. doi:10.1203/PDR.0b013e3181c13326

Yang, Y. T., and M. A. McElligott. 1989. Multiple actions of $\beta$-adrenergic agonists on skeletal muscle and adipose tissue. Biochem. J. 261(1):1-10. doi:10.1042/bj2610001 